\title{
Risk Management of Real Estate's Development and Construction Projects
}

\author{
Shen Jian-fei \\ School of Continuing Education \\ North China Electric Power University \\ Beijing, P.R.China \\ shenjianfei@263.net.cn \\ Yi Jing \\ School of Economics and Management \\ North China Electric Power University \\ Beijing, P.R.China \\ yijing_bj@126.com
}

\begin{abstract}
In this paper, we studied that how a real estate enterprise conduct risk identification, risk analysis and assessment, and risk coping and controlling when it was constructing a new project. In this paper, we set the fenglin residential construction project as our empirical case. Based on the data collected, we first utilized the expert investigation method and the fault tree analysis method to qualitatively define the risks during the whole construction period in order to draw the risk checklist. And then, based on the expert scoring method we quantitatively calculated the probability and importance level of the project in order to get the total risk degree. Lastly, we provided our suggestions into risk coping and managing for other real estate enterprises.
\end{abstract}

Keywords-fenglin construction project; real estate enterprises; development and construction projects; risk analysis and assessment; risk coping and controlling

\section{INTRODUCTION}

Engineering projects are large-scale, technically complex, object-oriented, long-period, risky and susceptible to construction time and fund ${ }^{[1]}$, which lead engineering projects to be quite possibly influenced by natural and social environment and other factors. The result is that parties involved in these projects are inevitably facing several sorts of risks. A construction project is a risky procedure, and if parties involved don't guard against these risks, it is likely to affect the progress of construction and even bring about serious consequences ${ }^{[2]}$. In recent years, housing prices rise over fluctuation and there tends to be more housing supplies and less land reserves. Coupled with stricter estate tax and credit policies, the risk degree of real estate industry is greatly increased compared to the previous ${ }^{[3]}$. Parties involved in real estate are eager to learn that what the hell the risks and its influence are and how to analyze and control these risks ${ }^{[4]}$. Based on this demand, we conducted a research on the risk management of real estate's development and construction projects.

\author{
Sun Qiao \\ School of Economics and Management \\ North China Electric Power University \\ Beijing, P.R.China \\ 245889801@qq.com
}

\section{CONCEPTS ON PROJECT RISK MANAGEMENT}

\section{A. Overview of project risks}

Project risks refer to the ones occur during the project's whole life, that is, all the uncertainties creating loss ${ }^{[5]}$. Risks can be divided into different types from different perspectives. They can be separated as basic risks and specific risks according to the scope involved ${ }^{[6]}$. Or they can be divided into natural, social, political or economic risks in basis of the reasons risks occurring ${ }^{[7]}$. In addition, risks can be split into property, personal and liability risks ${ }^{[8]}$

\section{B. Identification of project risks}

The essential task of project risk identification is to shift the uncertainties to understandable risk descriptions ${ }^{[9]}$. As a systematic process, risk identification has its own activities. The process is generally divided into five steps, that is, determine the target, define the most important parties, collect data, estimate risk situation and identify the potential risks reflected by direct or indirect symptoms ${ }^{[10]}$.

\section{Methods of project risk assessment}

There are a lot of project risk assessment methods, but here we just introduced the expert scoring method applied in the paper later. Expert scoring is one of the most common and easy-to-use methods in risk assessment ${ }^{[11]}$. The specific steps are as follows:

(1) Determine the probability of each risk factor to show its likelihood of occurrence. The total probability equals $100 \%$.

(2) Determine the importance level of each risk factor, likely smaller, small, middle, large, larger, and scoring them as $0.2,0.4,0.6,0.8$ and $1.0^{[12]} .0 .2$ represents the least and 1.0 the most.

(3) Multiply the probability value and the importance value. The result is the risk factor's score, that is each factor's risk degree. The sum of these scores are the total risk degree of the project $^{[13]}$. The higher risk degree is, the greater the risk criticality is. 


\section{EMPIRICAL CASE}

\section{A. Overview of the fenglin project}

Fenglin project locates at Shunyi district of Beijing, a residential project of the district's new town. The project is developed by the SSZY real estate firm, constructed by the seventh construction bureau of China State Construction Co. Ltd and corporately designed by several architecture design and research institutes.
The project covers a total area of $61,225.5$ square meters and is split into two time phases developing from south to north. The project plans to construct a total area of 36,030 square meters including 24,450 square meters overground and the remaining underground. It contains 17 single-family low-rise houses, 30 semi-detached low-rise houses and a transformer substation.

The specific investment estimation is shown in Table I.

TABLE I. INVESTMENT ESTIMATION

\begin{tabular}{|c|c|c|c|}
\hline & Project components & $\begin{array}{c}\text { Total cost } \\
\left(\mathrm{RMB} \text { Yuan } / \mathbf{m}^{2}\right)\end{array}$ & $\begin{array}{c}\text { Unit cost } \\
\left(\text { RMB Yuan } / \mathbf{m}^{2}\right)\end{array}$ \\
\hline 1 & Self-construction & $191,362,059$ & $5,311.19$ \\
\hline \multirow[t]{8}{*}{1.1} & Self-construction cost & $139,730,059$ & $3,878.16$ \\
\hline & Construction & $96,376,860$ & $2,674.91$ \\
\hline & Decoration & $26,621,493$ & 738.87 \\
\hline & Strong electricity (power lighting) & $8,684,262$ & 241.03 \\
\hline & Weak electricity & $1,814,378$ & 50.36 \\
\hline & Drainage & $6,194,740$ & 171.93 \\
\hline & Fire prevention & 4,326 & 0.12 \\
\hline & Other & 34,000 & 0.94 \\
\hline 1.2 & Main materials' price rise & $7,327,000$ & 203.36 \\
\hline 1.3 & Temporary materials' price adjustment & $36,385,000$ & $1,009.85$ \\
\hline 1.4 & Insulation Materials' price adjustment & $6,521,000$ & 180.99 \\
\hline 1.5 & Replacement materials' price adjustment & $1,399,000$ & 38.83 \\
\hline 2 & Subcontracting construction & $111,520,000$ & $3,095.20$ \\
\hline 2.1 & Outer walls & $74,310,000$ & $2,062.45$ \\
\hline 2.2 & Weak electricity & $5,000,000$ & 138.77 \\
\hline 2.3 & Gas & 900,000 & 24.98 \\
\hline 2.4 & Substation & $6,520,000$ & 180.96 \\
\hline 2.5 & Air Condition & $21,500,000$ & 596.72 \\
\hline 2.6 & Floor heating & $3,290,000$ & 91.31 \\
\hline 3 & Other construction & $20,220,000$ & 561.20 \\
\hline 3.1 & Elevator & $20,100,000$ & 557.87 \\
\hline \multirow[t]{2}{*}{3.2} & Fire prevention & 120,000 & 3.33 \\
\hline & Total cost & $323,102,059$ & $8,967.58$ \\
\hline
\end{tabular}

\section{B. Risk identification of the fenglin project}

Utilizing the expert investigation and the fault tree analysis method, based on the feedback of field visiting, oral consulting and questionnaire surveying, we summarized a risk checklist exhibiting the possible risk items faced by the project during the period from design to completion. After conducting the risk checklist, we identified the following risks existing in fenglin project.

(1)Technology risk. This risk includes that the design is inadequate and exists errors and the technical plan is unreasonable and immature.
(2)Material risk. The risk includes the supply and quality problems of raw materials, finished products, semi-finished products and some new materials and special materials.

(3) Management risk. This risk includes several parts, such as an inaccurate work decision, inadequate contract items and an unreasonable time schedule ${ }^{[14]}$. In addition, that the subcontractor or supplier default and the quality is unable to meet the contract's requirements are also within the management risk. For instance the time schedule risk, the project's time schedule is intense, plus 
higher client's requirements and changed policies and other inner and outer factors, which has delayed the completion time. This situation will affect the normal operation of the project.

(4) Fund risk. Due to some unexpected circumstances, the fund financed is inadequate to meet a growing fund need ${ }^{[15]}$. What's worse, part of the fund financed hasn't arrived yet. It is urgent to finance enough fund to ensure the construction.

(5)Safety risk. This risk includes industrial accidents, structure security risk and equipment safety risk.

(6)Risk of inconformity between design and site conditions. After comparing the construction drawings with the site condition, managers found that geological conditions are not very good, which would cause a large amount of ground treatment, increase the cost and delay construction completion.

(7)Rising prices risk. Prices raised much in the past several years. Possibilities are that prices continue to rise in the construction period, which will increase the risk of inflation and add material and stuff costs ${ }^{[16]}$.

(8)Personnel risk. This risk includes that key members change and personnel lack of working ability.

(9)Disasters risk. Experts points out that there may happen flood, thunder and other natural disasters ${ }^{[17]}$.

\section{Risk analysis and assessment of the fenglin project}

The project has a long construction period, a lot of parties involved and a large number of personnel, consequences of which are that there are all sorts of risks existing in each construction link. We first utilized expert investigation method to conduct a qualitative study on project's risks. Next, in identifying risks, we used experts' judgment to assess the importance level of possible risks and. Finally, we carried out a quantitative analysis on the project's risks using expert scoring method by combining the risk probability and risk importance level and got the result of risk degree. The specific steps are shown in Fig. 1 .

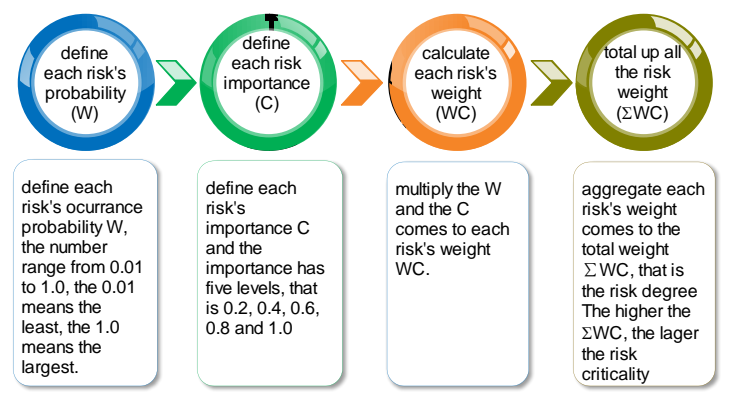

Figure 1. Steps of risk analysis and assessment

The comprehensive risk assessment using expert scoring is shown in Table 2.
TABLE II. RISK EVALUATION

\begin{tabular}{|l|r|r|l|l|l|l|l|}
\hline \multicolumn{1}{|c|}{ Risks } & \multicolumn{1}{|c|}{$\begin{array}{l}\text { Probab } \\
\text { ility } \\
\text { (W) }\end{array}$} & \multicolumn{5}{|c|}{ Risk's Importance(C) } & $\begin{array}{l}\text { Wei } \\
\text { ght } \\
\text { (W } \\
\text { C) }\end{array}$ \\
\hline & & 0.2 & 0.4 & 0.6 & 0.8 & 1.0 & \\
\hline technology & 0.2 & & & $\sqrt{ }$ & & & 0.12 \\
\hline management & 0.2 & & & & $\sqrt{ }$ & & 0.16 \\
\hline Material & 0.1 & & & & $\sqrt{ }$ & & 0.08 \\
\hline Fund & 0.15 & & & & $\sqrt{ }$ & & 0.12 \\
\hline Safety & 0.1 & & & $\sqrt{ }$ & & & 0.06 \\
\hline $\begin{array}{l}\text { geological } \\
\text { conditions }\end{array}$ & 0.1 & & & $\sqrt{ }$ & & & 0.06 \\
\hline economy & 0.05 & & $\sqrt{ }$ & & & & 0.02 \\
\hline Personnel & 0.05 & & $\sqrt{ }$ & & & & 0.02 \\
\hline disasters & 0.05 & $\sqrt{ }$ & & & & & 0.01 \\
\hline & & $\sum \mathrm{WC}=0.65$ & & \\
\hline
\end{tabular}

Table II demonstrates that the total risk degree of the project is 0.65 , a moderate risk, which is within the scope of the firm's acceptable level. In addition, we can see clearly the each factor's risk weight and a risk rank. Among these risks, management risk is the most concerned risk, and next the technology risk and the fund risk.

\section{Measures in risk coping and controlling}

According to the evaluation results, we put forward the corresponding risk response plan.

In order to carry out the above risk coping and controlling plan, we put forward the following strategies.

(1) Take advanced technical measures and improved organization measures.

Select effective workers and managers, take effective organization form, implement strict control and strengthen the work plan in the process of construction ${ }^{[18]}$. In particular, arrange the construction order reasonably, improve the technical measures, find problems timely, apply new technology, new materials and control the cost and quality strictly.

(2) Purchase insurances or claim guarantee to transfer risks.

Insurances include construction and installation insurance, third party liability insurance, social insurance, vehicles insurance and so on.

(3) Set up reasonable risk deposit.

The risk deposit is the preparation for risk from the financial view. The firm has reserved an amount of fund, $¥ 340,000$ in budget to offset or reduce the loss if risks occur.

(4) Strengthen risk warning and pre-controlling work

In the process of construction, continually collect and analyze all kinds of information and circumstances, and capture the risk signals in order to prepare and take effective measures timely. If risks occur, take timely measures to control them and reduce loss to the least and meantime ensure smooth implementation of the project. We should avoid interrupting construction and 
overrunning cost, and then try to obtain compensation to offset loss.

\section{CONCLUSIONS}

In this paper, we took the fenglin residential project as an empirical case to identify and evaluate risks possibly occurred during the construction. We calculated the comprehensive risk degree and came to the conclusion that the project was moderately risky, which was within the scope of the firm's acceptable level. The study effectively combined quantitative with qualitative method, which is widely applicable and well understanding. The results can be referred in risk management of real estate's development project. In the future work, we will deepen the quantitative research of risk management and study how to based on given conditions accurately calculate project's risks and returns and determine the optimal economic effect.

\section{REFERENCES}

[1]YANG Yin-hua. Analysis on the factors influencing engineering project's construction schedule and the control measures[J]. LuTianHua technology, 2013.2:148-153

[2]GAO Ya-ni. Study on the risk control system of the engineering guarantee agency[D]. Dongbei University of Finance and Economics, Dalian, China, 2007.

[3]LIU Jianhui, YUE Jingui. Risk management of Engineering project and its development in China[J]. Gansu agriculture, 2006, 5: 186

[4]YANG Ya-jun. Study on the system planning of real estate investment projects[D]. Nanjing Agricultural University, Nanjing, China, 2003.

[5]SHEN Jianming. Project's risk management[M]. China Machine Press, 2004:88—97
[6]YANG Zhi-yuan. Study on the risk control problems of China's state-owned enterprises[D]. Southwestern University of Finance and Economics, Chengdu, China, 2010.

[7]LIU Gui-zhen. Study on the overseas investment risk of China's oil enterprises[D]. China University of Geosciences, Beijing, China, 2012

[8]SHANG Wei. Study on the risk management of China's tax law enforcement[D]. Research Institute for Fiscal Science, Ministry of Finance, Beijing, China, 2012.

[9]ZHANG Wei. Study on the risk management of hydropower projects based on the grey fuzzy theory[D]. North China Electric Power University, Beijing, China, 2012.

[10]LI Ming. Study on the ecological management mode of project's risk management in the town's drainage automatic monitoring system[D]. Central South University, Changsha, China, 2012.

[11]ZHANG Jun. Study on the risk management of Foundation engineering[D]. South China University of Technology, Guangzhou, China, 2012.

[12] SUN Wen-jun, YU Zhi-gang. Study on the risk evaluation of real estate projects[J]. Shanxi Construction, 2012.5:62-64.

[13]GAO Xing-rong. Analysis on the contracting risk of international engineering projects[J]. China Tendering, 2012:25-29.

[14]QIN Wei. Study on the risk management of engineering projects[J]. Sichuan Construction, 2011.2:222-224

[15]RONG Hai-yun. Study on the risk-oriented fund management audit of power grid company[D]. North China Electric Power University, Beijing, China, 2012.

[16]ZHANG Bei, Study on the risk management of the Blue Mountains international construction project[D]. Ocean University of China, Qingdao, China, 2012.

[17]SUN Hua. Study on the risk management of real estate projects[D]. Xi'an Polytechnic University, Xi'an, China, 2013.

[18]WANG He-ping. Study on the timely decision of the new energy power projects based on the strategic corresponding theory[D] North China Electric Power University, Beijing, China, 2013. 